\title{
Persepsi Masyarakat Mengenai Wabah Pandemi Covid-19 (Studi Fenomenologi Pada Desa Kayuloe Barat Kecematan Turatea Kabupaten Jeneponto )
}

\author{
${ }^{1}$ Nasriadi, ${ }^{2}$ Nur Asmi \\ ${ }^{1}$ Sosiologi, Universitas Pattimura Ambon \\ 2Pendidikan Sosiologi, Unuversitas Muhammadiyah Makassar \\ Email : ari.smc.23@gmail.com
}

\begin{abstract}
This study aims to determine the public's perception of the COVID-19 pandemic outbreak in the West Loe wood village. Data collection techniques used in this study were observation, interviews, and documentation. The data sources that are processed are primary data sources and secondary data. And the research method used in this research is qualitative. The results of the research in this study are the public's perception of the COVID-19 pandemic outbreak in Kayuloe Barat Village, Turatea Subdistrict, Jeneponto Regency, that the community already understands the existence of the corona virus pandemic or covid 19 and the dangers it poses that are currently endemic, and understand how to prevent it to avoid from the corona virus or covid 19, namely by following the health protocols that have been implemented by the government, and with the covid 19 pandemic in the community causing several impacts such as economic impacts and social impacts so that society is getting more difficult because of the impact caused by this covid 19 pandemic.
\end{abstract}

Keywords : Perception, Society, Covid-19 Pandemic.

\begin{abstract}
Abstrak
Penelitian ini bertujuan untuk mengetahui persepsi masyarakat mengenai wabah pandemi covid 19 pada desa kayu loe barat. Teknik pengumpulan data yang digunakan dalam penelitian ini adalah dengan observasi, wawancara, dan juga dokumentasi. Sumber data yang diolah merupakan sumber data primer dan data sekunder. Dan metode penelitian yang digunakan dalam penelitian ini adalah Kualitatif. Hasil penelitian dalam penelitian ini adalah persepsi masyarakat mengenai wabah pandemi covid 19 pada Desa Kayuloe Barat Kecematan Turatea Kabupaten Jeneponto adalah masyarakat sudah paham tentang adanya pandemi virus corona atau covid 19 serta bahaya yang ditimbulkan yang sedang mewabah pada saat ini, dan paham cara pencegahan agar terhindar dari virus corona atau covid 19, yaitu dengan mengikuti protokol kesehatan yang telah diterapkan oleh pemerintah, dan dengan adanya pandemi covid $19 \mathrm{di}$ masyarakat menyebabkan beberapa dampak seperti dampak ekonomi dan dampak sosial sehingga masyarakat semakin sulit karena dampak yang di timbulkan oleh pandemi covid-19
\end{abstract}

Kata Kunci : Persepsi, Masyarakat, Pandemi Covid-19. 


\section{Aksiologi : Jurnal Pendidikan \\ dan Ilmu Sosial Volume : 1 No.2 (2021) \\ E-ISSN : 2747-2752 / P-ISSN : 2774-5686}

\section{PENDAHULUAN}

Corona virus adalah istilah fenomenal yang sering disebut oleh khalayak masyarakat dan istilah tersebut mengalami pro dan kontra dalam perdebatan. Secara umum bahwa virus covid-19 adalah kelompok virus yang dapat menyebabkan penyakit pada hewan atau manusia, beberapa jenis corona virus di ketahui menyebabkan infeksi saluran nafas pada manusia mulai dari batuk pilek, hinggah lebih serius seperti middle eyas respiratoring sindrom (mers) dan severe acute respiratory syndrom.

Dengan terus bertambahnya kasus yang terinfeksi Covid 19 di Indonesia maka pihak pemerintah mengeluarkan status darurat bencana terhitung mulai tanggal 29 februari 2020 hingga 29 mei 2020 terkait dengan adanya pandemi di Indonesia ini, pandemi virus corona dengan jumlah waktu 91 hari. Ini dilakukan karena terus bertambahnya korban yang terinfeksi oleh virus Corona maka pemerintah mengeluarkan status darurat bencana agar masyarakat lebih berhati-hati lagi dan tidak menganggap sepeleh virus ini. Pemerintah juga telah melakukan beberapa cara agar dapat menyelesaikan persoalan ini karena ini merupakan kasus yang sangat besar, salah satunya yaitu dengan melakukan sosialisasi gerakan social distancing.

Sulawesi Selatan adalah salah satu Provinsi yang di Indonesia yang tingkat kasus yang terinfeksi virus Covid 19 yang tertinggi dimana Sulawesi Selatan berada pada urutan ketiga kasus terbanyak. Kasus pertama Covid 19 di Sulawesi Selatan yang dilaporkan oleh gebernur Nurdin Abdullah dalam pers dikediamanya mengumumkan terdapak dua orang yang terinfeksi Covid 19 dan telah dilakukan isolasi dari kedua orang yang terinfeksi, dilaporkan satu diantaranya telah meninggal dunia Pasien yang meninggal itu diidentifikasi dengan Covid 285. Dia baru saja pulang umrah. Sepekan kemudian mengalami diare dan batuk, kata Gubernur Sulsel, Nurdin Abdullah, dalam keterangan persnya. Sejak diumumkannya kasus pertama yang terjadi di Sulawesi Selatan kasus covid 19 terus bertambah yang Kasus positif virus corona di Sulawesi Selatan mengalami rekor penambahan tertinggi pada Selasa $(9 / 6 / 2020)$ dengan mencapai 179 orang. Juru Bicara Gugus Tugas Percepatan Penanganan Covid-19 Sulsel Ichsan Mustari mengatakan penambahan 179 kasus positif itu tersebar di 8 kabupaten dan kota. Dengan penambahan tersebut, sudah ada 2.192 kasus positif Covid-19 di Sulsel sejak kasus pertama pada 19 Maret lalu. "Penambahan ada di Luwu Timur 115 kasus, Makassar 54 kasus, Wajo 1, Maros 3, Sidrap 1, Gowa 2, Luwu 2, dan Bulukumba.

Kabupaten Jeneponto adalah salah satu Kabupaten yang ada di Sulawesi Selatan yang masih zona hijau dalam kasus Covid 19 dan kasus pertama yang terjadi di Jeneponto yaitu seorang pemuda yang telah melakukan perjalanan dari kota Makassar yang dimana kota Makassar sudah termasuk kedalam zona merah, gejala yang diderita yaitu sesak nafas dan batuk, dan dengan tanggap pemerintah untuk mengisolasi pasien yang terinfeksi Covid 19 untuk mengurangi dan memutus rantai penyebaran, namun pada per tanggal 14 juli terdapat 29 kasus tambahan beberapa di antaranya adalah tenaga kesehatan, Ini terjadi karena disebabkan masih banyaknya masyarakat yang mengabaikan terhadap penerapan protokol kesehatan, misalnya saja mengunakan masker saat beraktifitas di luar rumah minimnya kesadaran itu dinilai bisa menjadi pemicu mudahnya penularan virus Corona antar satu orang 
ke orang lainya. Selain itu masih banyak juga juga masyarakat yang berpersepsi menganggap enteng virus ini,dengan tidak mengindahkan himbauanhimbauan pemerintah.

Di Desa Kayuloe Barat sendiri virus corona ini sangat berpengaruh dan menimbulkan kecemasan dengan adanya data yang terkonfirmasi terinfeksi virus Corona di Jeneponto ditambah banyaknya berita yang ditayangkan di televisi dan sosial media sehingga munculah persepsi-persepsi buruk tentang Covid-19 dan persepsi terhadap pemerintah karena masyarakat beranggapan pemerintah tidak bisa menyelesaikan permasalahan besar yang terjadi karena terus bertambah pasien kasus Covid 19 dalam satu hari sampai 100 kasus. Sehingga masyarakat semakin cemas akan adanya Covid-19 ini dan terbebani masalah ekonomi dimana masyarakat tidak bisa berkerja lagi dikarenakan sebagian dari masyarakat desa Kayuloe Barat adalah seorang perantau, mereka bekerja di kota Makassar dan Kota lain yang ada di Sulawesi Selatan dan sejak dikeluarkanya peraturan pemerintah untuk tetap di rumah maka masyarakat tidak bisa lagi pergi merantau di kota karena dilakukanya pembatasan sosial berskala besar (PSBB) di Kota Makassar dan Kabupaten lain.

Jeneponto terkhusus di desa Kayuloe Barat kecematan Turatea belum ada yang terinfeksi kasus Covid 19 tetapi dibeberapa kecematan di Jeneponto dilaporkan oleh gugus Covid 19 Jeneponto ada beberapa kasus yang terinfeksi Covid 19 sehingga masyarakat semakin was-was dan takut dengan adanya Covid 19 dan bukan itu saja masyarakat pun terbebani karena adanya Covid 19 ini, masyarakat tidak dapat bekerja yang dimana sebagian dari masyarakat yang ada di desa Kayuloe
Barat adalah seorang perantau dan dengan adanya Covid 19 masyarakat tidak dapat bekerja dan perekonomian semakin memburuk dikarenakan dilakukanya social distancing dan penutupan akses jalan perbatasan masyarakat semakin kesulitan untuk mencari nafkah.

\section{METODE}

Penelitian tentang persepsi masyarakat mengenai wabah pandemi Covid-19, peneliti menggunakan metode kualitatif. Dalam penelitian ini peneliti akan mengumpulkan data dan menggambarkan tentang persepsi masyarakat mengenai wabah pandemik Covid 19. Penelitian ini dilakukan agar dapat mengetahui dan memahami situasi di Desa Kayu Loe Barat yang dilakukan secara menyeluruh dan mendalam.

Penelitian ini mengunakan metode kualitatif dengan pendekatan fenomenologi serta menggunakan pendekatan fenomenologi, sebagai disiplin ilmu fenomelogi studi yang menpelajari fenomena seperti penampakan segala hal yang muncul dalam pengalaman kita, cara kita mengalami sesuatu dan makna yang kita miliki dalam pengalaman kita. Fokus penelitian fenomenologi tidak hanya sekedar fenomena akan tetapi pengalaman sadar dari sudut pandang orang pertama atau yang mengalaminya secara langsung.

\section{HASIL DAN PEMBAHASAN}

\section{a. Persepsi Masyarakat Di Desa Kayuloe Barat Kecematan Turatea Kabupaten Jeneponto Tentang Adanya Covid 19}

Covid 19 atau virus Corona bukan hanya di kota besar yang di indonesia yang terdampak adanya virus ini, tetapi juga meramba ke daerah-daerah terkecil yang ada di Indonesia seperti 
Kabupaten Jeneponto. Kasus pertama yang terjadi di Jeneponto yaitu seorang pemuda yang telah melakukan perjalanan dari kota Makassar yang dimana kota Makassar sudah termasuk kedalam zona merah, gejala yang diderita yaitu sesak nafas dan batuk, dan dengan tanggap pemerintah untuk mengisolasi pasien yang terinfeksi Covid 19 untuk mengurangi dan memutus rantai penyebaran kasus Covid-19 di Jeneponto. Masyarakat yang terkonfirmasi Covid 19 terus bertambah sampai saat ini, itu di karenakan kurangnya kesadaran masyarakat untuk tetep menarapkan protokol kesehatan dalam kesaharianya. Misalnya saja mengunakan masker saat beraktifitas di luar rumah minimnya kesadaran itu dinilai bisa menjadi pemicu mudahnya penularan virus Corona antar satu orang ke orang lainya. Selain itu masih banyak juga juga masyarakat yang berpersepsi menganggap enteng virus ini,dengan tidak mengidahkan himbauan-himbauan pemerintah. Masyarakat tahu dan paham adanya Covid 19 tetapi karena kurangnya kesadaran masyarakat dan menggap enteng virus ini serta banyaknya persepsi-persepsi masyarakat yang muncul sehingga masyarakat acuh terhadap bahaya yang yang akan disebakan oleh Covid 19 ini.

Informan menjelaskan bahwa:

"virus corona ini saya tau dari pemberitaan sosial media karena banyak beritanya,banyak juga teman yang share tentang virus ini, katanya virus ini dari china yang di sebarkan oleh hewan kayak kalelawar, terus virus ini masuk di indonesia karena masyakat luar negeri yang bawa dia terjangkit virus ini terus terkontaminasi sama masyarakat indonesia.".

(K/05/01/2021)
Seperti yang dikemukan informan yang di atas bahwa awal mula munculnya virus Corona di Indonesia yaitu berasal dari negara China dan menyebar ke belahan negara dunia, salah satu yaitu negara indonesia di negara Indonesia sendiri awal mula munculnya yaitu disebabkan karena adanya warga negara asing yang masuk ke negara Indonesia dan berinteraksi dengan masyarakat indonesia sehingga mengakibatkan terkontaminasi dan terjangkitlah virus corona atau covid 19.

"Kalau menurutku virus corona itu penyakit menular katanya dan bahaya sekali, saya tau ji itu virus itu kah sekarang heboh ki tentang covid ini. Semenjak heboh nya ini virus ini banyak sekali mi peraturanperaturan yang na kasi keluar pemerintah. Kaya ada juga permainan politik kayaknya di dalam ini, seperti ini biar sakit biasa jaki kalau ke rumah sakitki periksa na kira maki corona padahal penyakit biasaji" (kdr/04/01)

\section{b. Masyarakat di Desa Kayuloe Barat Kecematan Turatea Kabupaten Jeneponto Ter-hegemoni Adanya Pemberitaan Covid-19 Melalui Media Sosial.}

Dengan banyaknya pemberitaan tentang Covid 19 melalui media sosial yang telah menyita banyak perhatian masyarakat, bahkan media pun seolah mendukung dengan tidak lepasnya menberitakan tentang covid 19, mulai perkembangan serta dampak yang di timbulkan oleh covid 19 ini. Masyarakat pun selalu memantau bagaimana perkembagan covid 19, mulai dari berita kecil yang terus dibesar-besarkan sehingga menbuat masyarakat terhegomoni karena banyaknya pemberitaan yang tidak penting serta banyaknya berita hoax yang beredar di 
masyarakat. Dan memunculkan beberapa persepsi di kalangan masyarakat mulai dari yang katanya covid 19 ialah permainan politik dengan kepentingan orang-orang tinggi serta banyaknya pemberitaan yang di beritakan dan banyaknya berita hoax yang beredar sehingga menbuat masyarakat yang dimana pada awalnya sangat menpercayai tentang covid dan berubah kepercayaan masyrakat tentang covid mulai memudar sehingga banyak masyarakat yang tidak menerapkan protokol kesehatan dengan tidak memakai masker.

Adapun peneliti meminta tanggapan informan tentang persepsi masyarakat terhadap covid 19 pada Desa Kayuloe Barat Kecematan Turatea Kabupaten Jeneponto.

"iya pernah dengar melalui TV dan itu yang selalu diberitakan di tv sang itu mami muncul di tv di berikan selaluna tentang corona"(HK/wawancara 4/01)

Hasil wawancara yang dilakukan peneliti maka dapat diketahui bahwasanya masyarakat sudah tau tentang adanya virus corona atau covid 19 yang sedang ramai di bicarakan saat ini, di mana covid 19 terus saja merenggut nyawa masyarakat yang terjangkit virus ini dimana gejalanya mulai dari gejala ringan hingga yang menghawatirkan gejalanya pun bermacam-macam yang dirasakan oleh masyarakat mulai dari batuk biasa hingga berdahak serta sesak nafas dan flu.

Seperti yang dikatakan informan yang diatas bahwa dia mengetahi adanya covid 19 melalui media elektronik (televisi) karena dari awal munculnya covid 19 pemerintah sudah mengumungkan tentang adanya virus ini serta bahaya dan dampak yang akan terjadi ke masyarakat yang terjangkit virus ini semua itu agar masyarakat tetap hati-hati dan tetap menjaga kesehatanya agar tidak terjangkit dari virus corona, yang dikatan informan diatas sejalan dengan apa yang terjadi pada saat ini di media elektronik bahwasanya semuanya tentang pemberintaan virus corona atau covid 19.

Selanjutnya informan menberikan tanggapan bahwa

" siapa yang tidak tau virus corona kurasa semua orang sudah tau semua apalagi pemberitaanya itu terus mami kah bukan Cuma di tv di facebook juga banyak diberikan tentang virus ini dan banyak tong juga berita hoax na mi yang di beritakan tentang corona ini"( I/4/01)

Seperti yang di sebutkan informan di atas bahwa virus corona atau covid 19 pemberitaanya sudah ada dimana-mana bukan hanya diberitakan di media elektronik tetapi juga seluruh di sosial media, sehingga masyarakat semakin tau perkembangan dari virus corona dan masyarakat tau apa-apa saja gejala yang di timbulkan ketika terkena virus ini dan bagamaina cara menjaga diri agar terhindar dari virus corona dan banyak nya pemberitaan yang beredar baik di melalui media elektronik maupun media sosial sehingga ada beberapa oknum yang mengambil kesempatan dengan menyebarkan berita hoax demi kepentingan sendiri atau lain-lain. Sehingga dari kejadian itu menbuat masyarakat semakin cemas akan adanya virus corona karena banyak berita hoax yang menyebar melalui sosial media.

Wabah pandemi covid 19 adalah wabah penyakit yang menular yang telah menyerang seluruh negara-negara di dunia dengan adanya virus ini semua aktivitas terbatas dikarenakan 
diberlakukanya sosial distancing di masyarakat dan harus menggunakan masker semua itu diterapkan pemerintah untuk menjaga dan mengantipasi agar terhindar virus corona.

:"pakai masker, cuci tangan kalau pulang rumah, jauh-jauh dari orang yang sering batuk-batuk"

(HK/04/01/2021)

Sesuai dengan panduan protokol kesehatan yang di anjurkan oleh organisasi kesehatan dunia (WHO), untuk menjaga agar terhindar dari virus corona yaitu harus pakai masker ketika keluar rumah, cuci tangan saat pulang ke rumah karena bisa saja kita tidak sadar telah terkontaminasi sama masyarakat yang terjangkit virus ini dan menjaga jarak dengan orang yang sedang sakit seperti flu dan batuk ini untuk mengantisipasi agar terhindar dari virus ini.

"gampang saja ikuti arahan
pemerintah hindari kerumunan,
jangan sering-sering keluar rumah,
pakai masker kalau keluar rumah,
jangan lupa olah raga insya Allah
kitaa akan terhindar dari virus
corona"
$(R / 05 / 01 / 2021)$

Semenjak masuknya covid 19 di indonesia dan organisasi kesehatan dunia mengemunkan bahwa dunia darurat kesehatan maka pemerintah menghimbau seluruh masyarakat agar tetap di rumah dan melakukan sosial distancing atau menjaga jarak minimal 1 meter agar menghindari kerumunan dan selalu menggunakan masker, serta tetap melakukan olahraga agar tubuh tetap fit dan bugar. Karena kita tidak tau kapan kita sakit kapan kita terkena virus corona maka dari itu untuk menghindari agar tidak terjangkit virus ini maka harus tetap waspada tetap mengikuti protokol kesehatan. "kalau tidak mauki na kenna corona pakai ki masker jagan kumpulkumpul, cuci tangan ki kalau pulang rumah."

(A/05/01/2021)

Sama halnya yang dikemukakan informan sebelumnya bahwasanya untuk menjaga diri agar terhindar dari covid 19 ia dengan cara mengikuti himbauan pemerintah dan mengikuti protokol kesehatan yang telah di sampaikan pemerintah seperti menjaga jarak, menjahui kerumunan, serta selalu menggunakan masker saat keluar rumah dan jangan lupa rajin cuci tangan. Dengan mengikuti protokol kesehatan dapat memanilisir terjangkit dari virus corona.

\section{c. Dampak Sosial Covid-19 Terhadap Silahturahmi Antar Masyarakat}

Silahturahmi telah menjadi budaya di kalangan masyarakat, Bagi umat manusia, menjalin hubungan keluarga atau kekerabatan atau silaturahmi adalah sesuatu yang bersifat natural (alami) sekaligus cultural (bersifat budaya atau konstruksi sosial sebuah masyarakat). Alami karena setiap insan mempunyai naluri untuk berasosiasi dengan kerabat yang memiliki hubungan darah (blood ties). Jangankan manusia yang dalam Antropologi disebut sebagai human primates, kelompok non-human primates saja seperti apes, chimps, baboon, atau binatang sosial lain memiliki naluri atau kecenderungan alamiah untuk bersilaturahmi dengan kerabat.

Di masa pandemi covid 19 telah banyak merubah tatanan kehidupan sosial masyarakat dengan di terapkanya protokol kesehatan serta aturan-aturan lainya yang telah dikeluarkan oleh pemeritah, masyarakat dihimbau agar menjaga jarak serta menjauhui kerumunan agar memutus penyebaran covid 19, ini secara tidak lansung 
memutus jalinan silahturahmi yang telah lama di masyarakat diterapkan untuk menpererat tali persaudaran Covid 19 ini sangat berdampak bagi masyarakat.

" semenjak adanya virus corona kegiatan semakin terbatas karena adanya himbauan pemerintah untuk tetap dirumah kita juga ini sebagai bagian pemerintah desa harus menjadi contoh di masyarakat agar masyarakat tau cara menjaga diri supaya tidak kena virus ini, walaupun agak sulit ki karna di tau mi kalau desa kental sekali akan silaturahminya dan selalu gotong royong jadi semenjak di keluarkan himbauan bupati kita juga sebagai bagian pemerintah harus menerapkanya dan meneruskanya ke masyarakat,walaupun masih banyak masyarakat yang melanggar aturan ini"

(RH/04/01/2021)

Hasil wawancara yang dilakukan peneliti, informan mengatakan bahwasanya virus corona sangat berdampak pada kehidupan sosial masyarakat dimana diketahui bahwa masyarakat desa sangat kental dengan kekeluargaanya, dan silatarahmi sesama masih terus dijaga serta kehidupan gotong royong yang terus di junjung dan ini sudah dilakukan secara turun temurun di kehidupan masyarakat, sehingga ketika dikeluarkanya peraturan pemerintah tentang protokol masyarakat, masih banyak masyarakat yang tidak menerapkanya. Disebakan karena masyarakat sudah terbiasa dengan apa yang terjadi pada keseharian sebelumsebelumnya yang terus di lakukan sehingga masyarakat akan sulit beradaptasi terhadap hal yang baru, sama halnya dengan adanya covid 19 dan di anjurkanya masyarakat agar melakukan sosial distancing (kontak sosial) dan pysical distancing (kontak fisik).
Adapun beberapa informan yang menberikan penjelasan tentang dampak sosial yang dirasakan masyarakat kayuloe barat dengan adanya covid 19.

"Pengaruhnya jarangmiki ketemu teman-teman ta jarang miki juga pergi cerita- cerita cuman di medsos ji saling sapa dan Cuma bisa main game sendiri tidak bisa maki mabar ( main bareng) kah takutki kenna corona.

(R 05/01/2021)

Penjelasann yang diberikan oleh saudara riswan ( pemuda masyarakat), bahwa virus corona atau covid 19 ini sangat berpengaruh dalam kehidupanya, dikarenakan semenjak ada virus ini dia jarang ketemu sama temanmya hanya sekedar untuk bersilahturahmi. Sehingga sangat berdampak kehidupan sosial.

\section{d. Dampak Sosial Bagi Mahasiswa}

Dalam situasi wabah pandemi virus korona yang terjadi pada masyarakat Indonesia ini sangat berdampak pada kehidupan sosial, seperti dampak sosial, ekonomi,budaya dan juga berdampak pada dunia pendidikan, pemerintah pusat hingga daerah memberi kebijakan meliburkan seluruh lembaga pendidikan. Hal ini dilakukan sebagai upaya mencegah penularan virus corona. Akan tetapi pendidikan tidak berhenti begitu saja contohnya, saat ini seluruh perguruan tinggi menerapkan kuliah online atau daring seperti yang dirasakan oleh informan di bawa ini dia mengatakan bahwa:

"Pengaruhnya banyak sekali kalau dulu ketemu langsung bisa sekarang dibatasi kuliahpun sekarang cuma lewat zoom jadi sangat kurangmi interaksi ta sama temanta ataupun dosen ta" $(R / 05 / 01 / 2021)$ 
Covid-19 bukan hanya berpengaruh pada kehidupan sosial masyarakat tetapi juga pada dunia pendidikan seperti yang dirasakan riswan pada saat ini, bahwasanya semenjak ada covid 19 ini kuliahnya pun terhambat dimana pada awal muncul covid dunia perkulihan sempat di liburkan terus kuliah kembali tetapi dengan sistem yang berbeda dimana kulianya lewat online atau daring dan melalui sebuah aplikasi tanpa ada interkasi secara langsung baik sesama teman maupun dosen. Pembelajaran lewat daring menbuat beberapa universitas perguruan tinggi untuk menerapkannya agar pembelajaran tetap berlanjut dan mahasiswa dapat tetap mendapatkan ilmu pendidikan walaupun dengan cara yang berbeda, walaupun banyak kendala yang dirasakan oleh mahasiswa mulai dari media yang akan di pake seperti laptop dan handphone yang mendukung proses berjalanya pembelajaran, dan juga jaringan internet.

\section{e. Dampak Ekonomi}

Semenjak muncul dan adanya yang terinfeksi virus corona indonesia pada awal maret 2020, sejak itu berbagai cara dilakukan pemerintah untuk meredam dampak dari dampak pandemi covid 19 ini, dimana hampir seluruh sektor sektor yang terdampak tak hanya kesehatan dan dampak sosial tetapi juga berdampak pada sektor ekonomi. Pembatasan aktivitas juga berpengaruh pada aktivitas bisnis dunia yang kemudian sangat berimbas pada sistem perekonomian di masyarakat. Bukan hanya masyarakat baeah yang terdampak tetapi masyarakat menengah ke atas juga merasakan atas krisi ekonomi yang dirasakan di seluruh dunia dikarenakan di batasinya pergerakan, seperti tidak dapat lagi berkerja untuk memenuhui kebutuhan pokok ini juga sangat berpanguruh pada masyarakat di desa kayuloe barat kecematan turatea kabupaten jeneponto seperti yang dikatakan informan di bawah ini.

"terkait adanya covid ini yaa ini sangat berparuh ia sama masyarakat setempat apalagi semenjak diberlakukanya psbb walaupun di jeneponto tidak di berlakukan psbb hanya daerah lain tetapi berpangaruh juga pada masyarakat ini karana masyarakat sini selain bertani masyarakat sini juga ada yang merantau keluar daerah, ada juga seorang sopir. Yang perantau itu juga kesulitan karena tidak bisaki kemana-mana mau ke makassar kerja juga tidak bisa karena di makassar juga katanya di perketat pengamanan, yang sopir juga tidak bisa apa-apa tinggal mami di rumah karna biar keluarki tidak adaji penumpang na dapat karenakan sekolah juga di liburkan. Pokoknya covid ini berpengaruh sekali kegiatan pendapatan masyarakat."(RH/5/01/2021)

Berdasarkan tanggapan informan di atas bahwa virus corona sangat berdampak pada perekonomian masyarakat kayuloe barat, dimana kebanyakan masyarakat kayuloe barat selain bertani sebagai pendapatan utama ada juga yang merantau itu di lakukan untuk sebagai mencari penghasilan tambahan dan ada juga sebagian masyarakat yang menjadikanya pekerjaan utama dia adalah masyarakat yang tidak mempunyai lahan untuk di tempati bertani.

Adapun beberapa penjelasan yang di berikan informan tentang dampak ekonomi yang dirasakan masyarakat kayuloe barat dengan adanya covid 19 ini.

"iya sangat berdampak sekali" (H/05/01/2021) 
Keberadaan covid 19 atau corona virus ini dari awal muncul nya sudah sangat menpengaharui kehidupan masyarakat tidak hanya dunia kesehatan yang terimbas tetapi semua sektor baik bardampak pada sosial maupun ekonomi, dan covid 19 ini sangat berdampak pada perekonomian masyarakat karena bukan hanya melumpuhkan pergerakan masyarakat tetapi muga melupuhkan pencarian perekonomian masyarakat dan bukan hanya masyarakat biasa yang merasakan tetapi semua kalangan masyarakat.

\section{KESIMPULAN}

Persepsi masyarakat Desa Kayuloe Barat tentang wabah pandemi covid 19, ialah bahwa pandemi Covid 19 adalah suatu virus atau penyakit menular yang dapat menular ke siapa pun mulai dari anak-anak hingga lansia, dan Covid 19 dapat dicegah dengan mengikuti protokol kesehatan sesuai dengan yang dianjurkan, seperti harus rajin mencuci tangan setiap saat, menjaga jarak dengan orang lain minimal 1meter, serta harus menggunakan masker agar terhindar covid 19. Adapun Dampak sosial dan ekonomi yang dirasakan masyarakat Desa Kayuloe Barat dengan adanya Covid 19, dampak sosial yang dirasakan masyarakat karena adanya Covid 19 ialah dengan diberlakukannya sosial distancing (pembatasan kontak) dan physical distancing (pembatasan fisik), masyarakat sebagai mahluk sosial yang pada hakikatnya ialah saling berinteraksi satu sama lain, namun dengan diterpkan nya protokol kesehatan menbuat masyarakat untuk sulit berinteraksi dengan sesama. Bukan hanya dampak sosial yang dirasakan oleh masyarakat tetapi juga dampak ekonomi, dampak ekonomi yang dirasakan oleh masyarakat ialah tidak adanya lahan pekerjaan yang terbuka di masa pendemi ini sehingga masyarakat sulit untuk mendapatkan penghasilan tambahan untuk memenuhui kehidupan masyarakat.

\section{DAFTAR PUSTAKA}

Moleong, Lexy, J (2016).Metodologi Penelitian Kualitatif ( edisi revisi).

Nailul Mona. (2020). Konsep isolasi dalam jaringan sosial untuk meminimalisasi efek contagious (kasus penyebaran virus corona di indonesia) jurnal sosial humaniora terapan., 2(2), 117125.

Nursalam,Suardi, dan Syarifuddin (2016). Teori sosiologi, Klasik, Modern, Posmodern, Saintifik, Hermeneutik, Kritis, Evaluatif, dan Integratif.

Ritserdan goodman (2005). Teori Sosiologi. Kreasi Wacana. Yogyakarta

Schaffer. (2000). Pencegahan Infeksi dan Praktek yang Aman. Jakarta: EGC.

Semiun, Yustinus. (2006). Kesehatan Mental 3. Yogyakarta: Penerbit Kanisius.

Suci, Fellyanda. 2020. Cerita Lengkap Asa Mula Munculnya Virus Corona di Wuhan.

Shari, M. (2020). Proses Pembelajaran Daring di Tengah Antisipasi Penyebaran Virus Corona Dinilai Belum Maksimal. Pikiran Rakyat com. Pengelola Web

Sugiyono. (2012). Metode Penelitian Kuantitatif Kualitatif dan $R \& D$. Alfabeta.

Wirawan (2012).Teori-teori sosial dalam tiga paradigma(fakta sosial, definisi sosial, dan perilaku sosial) 
WHO. (2020). The World Health Report 2020. Geneva: WHO

Yurianto, Ahmad, Bambang Wibowo, K. P. (2020). pedoman pencegahan dan pengendalian coronavirus disease (covid-19) (M. I. Listiana Azizah, Adistikah Aqmarina (ed.)

\section{Sumber Online}

Kemenkes RI. 2020a. "Pedoman Pencegahan Dan Pengendalian Coronavirus Disease(COVID19).(Diakses pada tanggal 07/08/2020)

Kemenkes RI. 2020b. "Tentang Novel Coronavirus (Ncov)." Retrieved April 25, 2020.(Diakses pada tanggal $07 / 08 / 2020$ )

Koesmawardhani, N. W. (2020, Maret 17). Pemerintah Tetapkan Masa Darurat Bencana Corona hingga 29 Mei 2020. Detiknews. Diunduh dari https://news.detik.com/berita/d49 42327/pemerintah-tetapkan-masadarurat-bencana-corona-hingga-29$\underline{\text { mei-2020 }}$

Sebayang, R. (2020, Januari 31). Awas! WHO Akhirnya Tetapkan Corona Darurat Global. CNBC Indonesia. Diunduh dari https://www.cnbcindonesia.com/ne ws/20200131060856-4134146/awas- who-akhirnyatetapkan-corona-darurat-global 